\title{
RISK ASSESSMENT OF BRONCHOPULMONARY PATHOLOGY IN THE WORKERS OF COAL AND ASBESTOS PROCESSING INDUSTRIES BASED ON A HYGIENIC ASSESSMENT OF THE CONDITIONS OF WORK AND THE RESULTS OF CLINICAL-AND-GENEALOGICAL STUDY
}

Cherniuk V.I., Andrushchenko T.A., Soloviov A.I., Goncharov A.E.

\section{ОЦПКА РИЗИКУ РОЗВИТКУ БРОНХОЛЕГЕНЕВОЇ ПАТОЛОГІЇ У ПРАЦВВНИКІВ ВУГІЛЬНОӦ ТА АЗБЕСТОПЕРЕРОБНОӦ ПРОМИСЛОВОСТІ НА ОСНОВІ ГІГІЕНІЧНОЇ ОЦПККИ УМОВ ПРАЦІ ТА РЕЗУЛЬТАТІВ КЛПНКО-ГЕНЕАЛОГЧНОГО ОБСТЕЖЕННЯ}

\section{ЧЕРНЮК B.I., АНДРУЩЕНКО Т.А., СОЛОВЙОВ О.І., ГОНЧАРОВ О.Е. \\ ДУ «Інститут медицини праці ім. Ю.І. Кундієва Національної академії медичних наук України», м. Київ \\ Ключові слова: бронхолегенева патологія, оцінка ризику, гігієнічна оцінка умов праці, клініко- генеалогічний аналіз.}

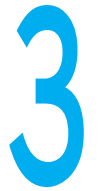

береження

здоров'я працюючого населення у розвинених країнах світу було і залишається одним 3 пріоритетів державної політики, оскільки здоров'я $€$ найважливішим показником якості трудового потенціалу і значною мірою визначає економічний та соціальний розвиток суспільства [1-3]. Разом з тим в Україні щорічно реєструються 6-8 тисяч професійних захворювань, причому у структурі професійної захворюваності бронхолегенева

(БЛП) становить понад 50\% [4]. Заміна ідеології профілактичної медицини останніми роками вимагає застосування ризикоорієнтованого підходу в оцінці загроз здоров'ю для працівників 3 шкідливими і небезпечними умовами праці залежно від накопичених доз шкідливих виробничих факторів та показників стану їхнього здоров'я $[5,6]$.

Стає очевидним, що ймовірнісний підхід до оцінки ризику виникнення професійних захворювань $€$ більш

ОЦЕНКА РИСКА РАЗВИТИЯ БРОНХОЛЕГОЧНОЙ ПАТОЛОГИИ У РАБОТНИКОВ УГОЛЬНОЙ И АСБЕСТОПЕРЕРАБАТЫВАЮЩЕЙ ПРОМЫШЛЕННОСТИ НА ОСНОВЕ ГИГИЕНИЧЕСКОЙ ОЦЕНКИ УСЛОВИЙ ТРУДА И РЕЗУЛЬТАТОВ КЛИНИКОГЕНЕАЛОГИЧЕСКОГО ИССЛЕДОВАНИЯ

Чернюк В.И., Андрущенко Т.А., Соловьев А.И., Гончаров А.Э.

ГУ «Институт медицины труда им. Ю.И. Кундиева Национальной академии медицинских наук Украины», г. Киев

При установлении причинно-следственной связи развития бронхолегочной патологии с условиями труда работников основных профессий угольной и асбестоперерабатывающей промышленности до сих пор окончательно не установлена роль отягощенной наследственности. В частности, может ли быть отягощенная наследственность бронхолегочной патологии общей причиной или фактором риска возникновения профессиональных заболеваний дыхательной системы?

Цель работы - выяснить зависимость развития бронхолегочной патологии у работников угольной и асбестоперерабатывающейпромышленности от влияния условий труда и наличия отягощенной наследственной предрасположенности к заболеваниям дыхательной системы.

Материалы и методы исследования информационно-аналитические (изучение санитарно-гигиенических характеристик условий труда, материалов предварительных научных отчетов); клинико-генеалогическое исследование (составление и анализ 215 родословных).

Результаты. Установлена причинно-следственная связь бронхолегочной патологии с условиями труда работников основных профессий угольной и асбестоперерабатывающей промышленности. Нижняя граница относительного риска $(R R)-1,69$, верхняя - 1,76 единиц отвечают среднему риску развития бронхолегочной патологии с этиологической долей фактора условий труда $E F(1)$ 41-43\%. Выяснено, что в семьях с отягощенной наследственностью бронхолегочной патологией риск ее развития в два раза выше по сравнению с контрольной группой ( $\left.F A=2,1 ; P \leq 0,001 ; \chi^{2}=16,75\right)$. Оценка этиологической доли риска влияния отягощенной наследственности в семьях респондентов исследования $E F(2)$ свидетельствует о значительной (47-48\%) доле вклада этого фактора в развитие бронхолегочной патологии. В семьях, где одновременно прослеживались отягощенная наследственность заболеваниями дыхательной системы и профессиональная преемственность, риск развития в 1,5 раза выше по сравнению с семьями, где отсутствуют эти фактры $\left(F A=1,5 ; P \leq 0,01 ; \chi^{2}=5,65\right)$.

Выводы. Относительно низкий риск развития бронхолегочной патологии в анализированной выборке можно объяснить существованием других факторов риска или общей причины, или особенностями неслучайного отбора в группу контроля.

Полученные коэффициенты семейной агрегации FA свидетельствуют о том, что в семьях с отягощенной наследственностью бронхолегочной патологией и профессиональной преемственностью риск развития данной патологии выше по сравнению с семьями без позитивных семейных случаев заболеваний дыхательной системы.

Ключевые слова: бронхолегочная патология, оценка риска, гигиеническая оценка условий труда, клинико-генеалогический анализ.

( Чернюк В.І., Андрущенко Т.А., Соловйов О.І., Гончаров О.Е. СТАТТЯ, 2019. 


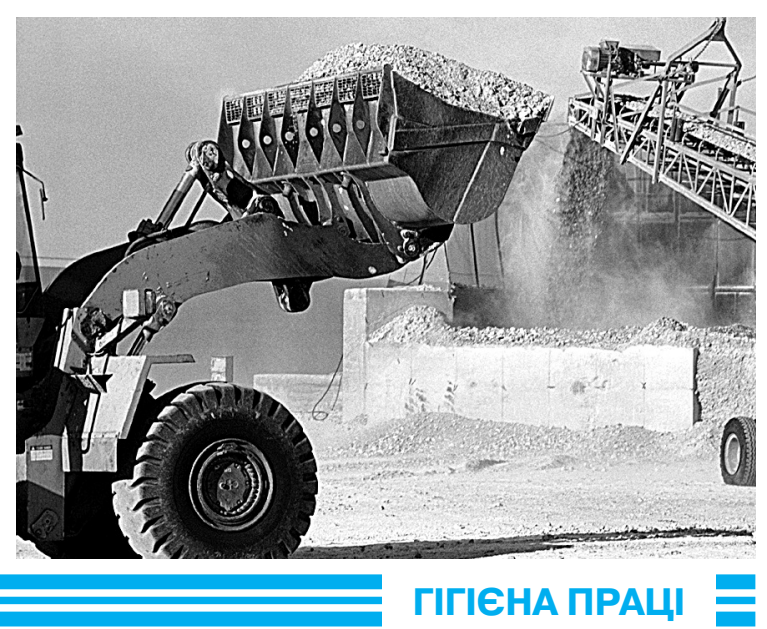

коректним, ніж традиційна гігієнічна оцінка відповідності умов праці санітарним нормативам [3, 6, 7]. Пошук факторів ризику розвитку БЛП $€$ надзвичайно актуальним [2, 8-12].

Слід зазначити, що серед нозологічних форм хронічної БЛП немає патологічних процесів, які визначалися би як облігатні передракові захворювання, у той час як до факультативних передракових станів належать процеси, коли спостерігається плоскоклітинна метаплазія бронхіального епітелію.

До виробничих факторів ризику, які потенційно можуть впливати на розвиток БЛП, найчастіше відносять промислові аерозолі переважно фіброгенної дії, несприятливий мікроклімат, важкість і напруженість праці, проте роль цих чинників у даному випадку остаточно не з'ясована.

Отже, визначення ролі впливу шкідливих виробничих факторів у сполученні з факторами індивідуальної схильності до розвитку БЛП залишається актуальним напрямком досліджень для розробки заходів профілактики стосовно даної групи хвороб [2, 4, 8-12].

Мета роботи - 3'ясувати залежність розвитку бронхолегеневої патології у працівників вугільної та азбестопереробної промисловості від впливу умов праці та наявності обтяжливої спадкової схильності до захворювань бронхолегеневої системи.

Методика. Загальноприйнятими етапами дослідження при оцінці професійного ризику $є$ ідентифікація небезпеки, виявлення шкідливих і небезпечних факторів на робочому місці, які можуть слугувати факторами підвищеного ризику порушень здоров'я у працівників; визначення серед них провідного фактора; оцінка значимості комбінованого впливу досліджених факторів; оцінка експозиційної дози впливу, виходячи з рівня фактора і часу його дії; аналіз даних про стан здоров'я і захворюваність експонованих контингентів, що увійшли до програми дослідження. атестації робочих місць. Загальну гігієнічну оцінку умов праці, яка необхідна для прогнозування потенційних ризиків виникнення БЛП у досліджених, дано за критеріями Державних санітарних норм та правил «Гігієнічна класифікація праці за показниками шкідливості та небезпечності факторів виробничого середовища, важкості та напруженості трудового процесу», які затверджені наказом Міністерства охорони здоров'я України від 08.04 .2014 р. № 248 (ДСНтаП ГКП № 248). Усі працівники основних професій АЦЗ і вугільних шахт за результатами гігієнічної оцінки умов праці розподілялися згідно з критеріями ДСНтаП ГКП № 248 на 4 класи та ступені (клас умов праці - КУП), 1-й клас - оптимальні (КУП 1), 2-й клас - допустимі (КУП 2), 3-й клас - шкідливі 1-4 ступеня (КУП 3.1, 3.2, 3.3, 3.4), 4-й клас - небезпечні (КУП 4).

Рівень шкідливості та небезпечності умов праці у кожній професії визначали шляхом підсумовування бальних оцінок відповідно до категорій та ступенів шкідливості КУП: 0 балів - для 1-го та 2-го класів умов праці; 1, 2, 3, 4 бали відповідно до КУП 3.1, 3.2, 3.3. 3.4; 5 балів - для КУП 4 - для небезпечних умов праці.

Для порівняльного аналізу було сформовано групи дослідження та контролю. Групу дослідження склали працівники АЦЗ і шахтарі з БЛП (хронічний бронхіт, хронічне обструктивне захворювання легенів, пневмоконіоз). До контрольної групи увійшли працівники АЦЗ і шахтарі, в анамнезі яких не було БЛП, проте стаж роботи та умови праці були співставні з даними респондентів групи дослідження. 
Клініко-генеалогічне обстеження проводили у два етапи: складання родоводу і генеалогічний аналіз. При складанні родоводу визначалися дані про кожного члена родини 3 точною вказівкою його спорідненості щодо пробанда, після чого графічно відтворювали родовід 3 застосуванням прийнятих стандартних символів. За допомогою генеалогічного аналізу встановлювали ступінь спорідненості зв'язків та досліджували обтяжливу спадковість на БЛП серед родичів пробанда $[1,3,8,10]$.
У подальшому встановлювали осіб, які мають родичів, що також працювали у шкідливих і небезпечних умовах праці та визначали коефіцієнт родинної агрегації (FA від англ. Family aggregation) за формулою 1 , $x$ де $\mathrm{X}$ - частота по$\mathrm{FA}=\frac{\mathrm{x}}{\mathrm{y}}$, (1) ширеності родинних випадків БЛП у дослідній групі, Y - частота поширеності родинних випадків БЛП у групі контролю.

Методологія оцінки ризику базується на фундаментальних розробках [10, 13]. Так, розрахунок відносного ризику
(RR) розвитку БЛП у респондентів досліджень проведено за формулою 2, дисперсія показника відносного ризику за формулою 3, яка необхідна для обчислення 95\% довірчого інтервалу для відносного ризику за формулою 4:

$A_{1}, A_{0}$ де $R R$ - від$R R=\frac{A_{1}}{N_{1}} / \frac{A_{0}}{N_{0}}$, (2) носний ризик; $\operatorname{var}[\ln (R R)]=\frac{N_{1}-A_{1}}{N_{1} \cdot A_{1}}+\frac{N_{0}-A_{0}}{N_{0} \cdot A_{0}}$,

де $\ln (R R)$ - дисперсія (D);

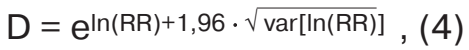

де е - основа натурального

Вихідні дані для розрахунків

Таблиця 1

\begin{tabular}{|c|c|c|c|c|c|c|c|}
\hline & \multicolumn{2}{|c|}{ Експоновані } & \multirow{2}{*}{ Загалом } & \multirow{2}{*}{$\mathrm{RR}(\mathrm{Cl})$} & \multirow{2}{*}{$E F, \%$} & \multirow{2}{*}{$\begin{array}{l}\text { Оцінка [10] } \\
\text { ризику БЛП }\end{array}$} \\
\hline & & Група № 1 & Група № 2 & & & & \\
\hline \multirow{2}{*}{$\begin{array}{l}\text { Хворі } \\
\text { на Блп }\end{array}$} & Так & $A_{1}$ & $A_{0}$ & A & \multirow{3}{*}{$\begin{array}{c}\text { Відносний } \\
\text { ризик RR } \\
\text { (довірчий } \\
\text { інтервал) }\end{array}$} & \multirow{3}{*}{$\begin{array}{c}\text { Етіологічна } \\
\text { частка } \\
\text { ризику, \% }\end{array}$} & \multirow{3}{*}{$\begin{array}{c}\text { За } \\
\text { критеріями } \\
\text { табл. } 2\end{array}$} \\
\hline & $\mathrm{Hi}$ & $\mathrm{N}_{1}-\mathrm{A}_{1}$ & $\mathrm{~N}_{0}-\mathrm{A}_{0}$ & $N-A$ & & & \\
\hline \multicolumn{2}{|l|}{ Разом } & $\mathrm{N}_{1}$ & $\mathrm{~N}_{0}$ & $\mathrm{~N}$ & & & \\
\hline
\end{tabular}

Категорії оцінки причинно-наслідкових відносин [10]

Таблиця 2

\begin{tabular}{|c|c|c|c|c|c|}
\hline $0<\mathrm{RR}<1,0$ & $1,0<\mathrm{RR}<1,5$ & $1,5<\mathrm{RR}<2,0$ & $2,0<\mathrm{RR}<3,2$ & $3,2<\mathrm{RR}<5,0$ & $\mathrm{RR}>5,0$ \\
\hline $\mathrm{EF}=0$ & $\mathrm{EF}<33 \%$ & $\mathrm{EF}=34-50 \%$ & $\mathrm{EF}=51-66 \%$ & $\mathrm{EF}=67-80 \%$ & $\mathrm{EF}=81-100 \%$ \\
\hline Нульовий & Малий & Середній & Високий & Дуже високий & Майже повний \\
\hline \multicolumn{2}{|c|}{ Загальні профзахворювання } & \multicolumn{3}{|c|}{ Виробничозумовлені } & $\begin{array}{c}\text { Професійні } \\
\text { захворювання }\end{array}$ \\
\hline
\end{tabular}

Гігієнічні оцінки умов праці працівників основних професій вугільних шахт

Таблиця 3 і азбестоцементних заводів

\begin{tabular}{|c|c|c|c|c|c|c|c|c|}
\hline \multirow{3}{*}{ Робоче місце } & \multicolumn{8}{|c|}{$\begin{array}{c}\text { Клас та ступінь (бал) шкідливості виробничих факторів згідно } \\
\text { з п. } 3 \text { розділу III ДСНтаП ГКП № } 248\end{array}$} \\
\hline & \multirow{2}{*}{$\begin{array}{c}\text { Пил } \\
\text { фібро- } \\
\text { генної } \\
\text { дії }\end{array}$} & \multicolumn{2}{|c|}{ Вібрація } & \multirow{2}{*}{ Шум } & \multirow{2}{*}{$\begin{array}{l}\text { Мікро- } \\
\text { клімат }\end{array}$} & \multicolumn{2}{|c|}{$\begin{array}{l}\text { Трудовий } \\
\text { процес }\end{array}$} & \multirow{2}{*}{$\begin{array}{c}\text { Загальна } \\
\text { оцінка } \\
\text { умов праці } \\
\text { (сума } \\
\text { балів) }\end{array}$} \\
\hline & & локальна & загальна & & & $\begin{array}{l}\text { важ- } \\
\text { кість }\end{array}$ & $\begin{array}{l}\text { напру- } \\
\text { женість }\end{array}$ & \\
\hline $\begin{array}{l}\text { Забійник на відбійних } \\
\text { молотках }\end{array}$ & $3.4(4)$ & $3.4-4(4-5)$ & & $3.3(3)$ & $3.2(2)$ & $3.3(3)$ & $3.3(2)$ & $4(19-20)$ \\
\hline $\begin{array}{l}\text { Прохідник } \\
\text { (комбайнова технологія) }\end{array}$ & $3.4(4)$ & - & $\begin{array}{l}3.3-4(3- \\
5)\end{array}$ & $3.4(4)$ & $3.2(2)$ & $3.3(3)$ & $3.2(2)$ & $4(18-20)$ \\
\hline Те ж (буро-вибухова) & $3.4(4)$ & $3.3-4(3-5)$ & - & $3.4(4)$ & $3.2(2)$ & $3.3(3)$ & $3.2(2)$ & $4(18-20)$ \\
\hline ГОЗ (лави) & $3.4(4)$ & $3.4(4)$ & & $3.3(3)$ & $3.2(2)$ & $3.3(3)$ & $3.2(2)$ & $4(18)$ \\
\hline Машиніст ЛФМ & $3.3(3)$ & & $3.1(1)$ & $3.2(2)$ & $3.2(2)$ & & $3.1(1)$ & $3.3(9)$ \\
\hline Оператор 3В & $3.3(3)$ & & & $3.2(2)$ & $3.2(2)$ & & $3.1(1)$ & $3.3(8)$ \\
\hline Дозувальник азбесту & $3.4(4)$ & & & & $3.1(1)$ & $3.2(2)$ & & $3.4(7)$ \\
\hline Машиніст крана (кранівник) & $3.2(2)$ & & $3.1(1)$ & $3.1(1)$ & $3.1(1)$ & & $3.2(2)$ & $3.2(7)$ \\
\hline
\end{tabular}


RISK ASSESSMENT OF BRONCHOPULMONARY PATHOLOGY IN THE WORKERS OF COAL AND ASBESTOS PROCESSING INDUSTRIES BASED ON A HYGIENIC ASSESSMENT

OF THE CONDITIONS OF WORK AND THE RESULTS OF CLINICAL-AND-GENEALOGICAL STUDY

Cherniuk V.I., Andrushchenko T.A.,

Soloviov A. I., Goncharov A.E.

SI «Kundiev Institute of Occupational Health, National Academy of Medical Sciences of Ukraine", $\underline{\text { Kyiv }}$

Introduction: When establishing the causal relationship of the development of bronchopulmonary pathology with the conditions of work in the workers of main professions in coal and asbestos processing industries, a role of burdened hereditary has not been fully established yet. In particular, can burdened hereditary for bronchopulmonary pathology be a common cause or risk factor for the occurrence of the occupational diseases of respiratory system?

Objective: We found out the dependence of the development of bronchopulmonary pathology among the workers of coal and asbestos processing industries from the influence of the conditions of work and the presence of burdened hereditary susceptibility to respiratory system diseases. Materials and methods: We applied informativeand-analytical methods: the study of sanitary-andhygienic characteristics of the conditions of work, materials of the preliminary scientific reports; clinical-and-genealogical research (compilation and analysis of 215 pedigrees).

Results: The causal relationship of the bronchopulmonary pathology with the working conditions of workers in the main professions of the coal and asbestos processing industry has been established. A lower limit of the relative risk $(R R)$ of 1.69 and an upper one of 1.76 units are in compliance with an average risk of the development of bronchopulmonary pathology with an aetiological share of the factor of the conditions of work EF (1) of 41-43\%. It was found that in the families with burdened heredity of bronchopulmonary pathology, the risk of its development is two times higher than in the control group $\left(F A=2.1, P \leq 0.001 ; \chi^{2}=16.75\right)$. Estimation of the aetiological share of the risk of the influence of burdened heredity in the families of the respondents in the EF study (2) indicates a significant (from 47 to $48 \%$ ) share of the contribution of this factor to the development of bronchopulmonary pathology. In the families where burdened heredity of the respiratory system and professional succession were observed simultaneously, the risk of the development was 1.5 times higher in comparison with the families where there was no burdened history of respiratory system diseases and professional succession (FA = 1.5; $P \leq 0.01 ; \chi^{2}=5.65$ ).

Conclusions: A relatively low risk of the development of bronchopulmonary pathology in analyzed sample can be explained by the existence of other risk factors or a common cause, or features of a non-random selection into the control group.

The obtained coefficients of the family aggregation indicate that in the families with burdened heredity of bronchopulmonary pathology and occupational succession, a risk of the development of this pathology is higher in comparison with the families without positive family cases of respiratory system diseases.

Keywords: bronchopulmonary pathology, risk assessment, hygienic assessment of the conditions of work, clinical-and-genealogical analysis. логарифму, e $\approx 2,7128$, a In натуральний логарифм.

Позначення до формул 2 і 3 та вихідні дані для розрахунку відносного ризику (RR), дисперсії (D) і довірчого інтервалу (Cl) RR розвитку БЛП у респондентів досліджень наведено у таблиці 1.

Етіологічну частку ризику (EF) розраховано за формулою:

$\mathrm{EF}=100 \cdot(\mathrm{RR}-1) / \mathrm{RR} \%$. (5)

Оцінку причинно-наслідкових відносин між ризиком розвитку БЛП у респондентів дослідження під впливом виробничих факторів проведено за категоріями, зазначеними у таблиці 2.
Сума етіологічних часток для усіх достатніх і додаткових причин розвитку БЛП має такий вигляд:

$$
E F(1)+E F(2)=\%,(6)
$$

де $E F(1)$ - етіологічна частка впливу факторів виробничого середовища у розвитку БЛП; EF(2) - етіологічна частка генетичної компоненти (схильності) у розвитку БЛП.

Отримані результати опрацьовано методом математико-статистичного аналізу 3 використанням ліцензійного пакета прикладних програм (Excel 2016). Для оцінки відмінностей між двома незалежними вибірками шляхом пере- вірки статистичних гіпотез $\left(\mathrm{H}_{0}\right.$; $\mathrm{H}_{1}$ ) застосовано критерій $\chi^{2}$, значення $\mathrm{P}<0,05$ вважали достовірним.

Результати та обговорення. Загальна гігієнічна оцінка умов праці свідчить, що на робочих місця прохідників, зайнятих у комбайновій та/або буровибуховій технології проведення виробок, ГОЗ (лави), забійників на відбійних молотках за критеріями ДСНтаП ГКП № 248 мають місце шкідливі та небезпечні умови праці (КУП 3.3-4) з максимальною сумою балів (18-20). Фактори виробничого середовища (пил фіброгенної дії, шум), фактори

Таблиця 4

Результати оцінки ризику розвитку БЛП з розрахунком етіологічної частки EF(1), обумовленої впливом шкідливих виробничих факторів

\begin{tabular}{|c|c|c|c|c|c|c|}
\hline & \multicolumn{2}{|c|}{ Експоновані групи } & \multirow{2}{*}{ Загалом } & \multirow{2}{*}{$\begin{array}{c}\text { Відносний ризик } \\
\text { RR (Cl) }\end{array}$} & \multirow{2}{*}{$E F(1), \%$} & \multirow{2}{*}{$\begin{array}{l}\text { Оцінка ризику } \\
\text { розвитку БЛП }\end{array}$} \\
\hline & № 1 & № 2 & & & & \\
\hline Випадки БЛП «+» & 22 & 27 & 49 & 1,724 & & \multirow{3}{*}{ Середній ризик } \\
\hline Контроль & 47 & 119 & 166 & $(1,69-1,76)$ & $41-43$ & \\
\hline Разом & 69 & 146 & 215 & & & \\
\hline
\end{tabular}


трудового процесу (важкість та напруженість праці) віднесено до максимального класу та ступеня шкідливих умов праці, а локальна та загальна вібрація - навіть до небезпечного (КУП 4). Результати комплексної гігієнічної оцінки умов праці респондентів дослідження представлено у таблиці 3.

На робочих місцях працівників основних професій АЦЗ (дозувальника азбесту, оператора ЗВ, машиніста ЛФМ, машиніста крана - кранівника), сума балів від 7 до 9 свідчить про менш шкідливі умови праці (КУП 3.2-3.4) порівняно 3 гірниками вугільних шахт. Очевидно, що вплив на організм працівників понаднормативних концентрацій пилу переважно фіброгенної дії (КУП 3.3-3.4), несприятливих параметрів мікроклімату та емоційних навантажень (КУП 3.1-3.2) є характерними для обох досліджених груп. Вплив небезпечних та шкідливих рівнів вібрації (КУП 4), шуму (КУП 3.3-3.4), а також важкої фізичної праці (за інтегральною оцінкою - КУП 3.3) більш характерний для основних професійних груп гірників вугільних шахт.

Виявлені відмінності умов праці працівників вугільних шахт і АЦЗ враховані нами при визначенні причиннонаслідкових зв'язків між факторами ризику і частотою випадків БЛП, а також при інтерпретації даних клінікогенеалогічного обстеження респондентів дослідження. При розрахунках ймовірності розвитку БЛП загальна вибірка із 215 експонованих на шкідливі умови праці працівників була розподілена за дві групи. Група № 1 включала переважно працівників основних професій вугільних шахт $(95,7 \%)$ та АЦЗ $(4,3 \%)$ (КУП $3,4)$, які були об'єднані за домінуючим шкідливим фактором - «пил фіброгенної дії». Групу № 2 порівняння склали працівники основних та допоміжних професій вугільних шахт та АЦЗ, що працювали у менш шкідливих умовах праці (КУП 2-3.2). У таблиці 4 представлено результати оцінки ризику розвитку БЛП з розрахунком етіологічної частки EF(1), обумовленої впливом шкідливих виробничих факторів, насамперед пилом переважно фіброгенної дії (КУП 3.3-3.4).

Очікуваний ризик розвитку БЛП для працівників зі шкідливими умовами праці (КУП 3.33.4) 3 домінуючим пиловим фактором має становити $\mathrm{RR}>5,0$. y нашому випадку нижня та верхня межі RR становили 1,69-1,76 одиниць відповідно, що відповідає середньому ризику розвитку БЛП з етіологічною часткою фактора умов праці EF(1) 41-43\% Такий відносно низький ризик розвитку БЛП в аналізованій групі можна пояснити існуванням інших факторів ризику або спільної причини, чи особливостями невипадкового відбору групи контролю.

У результаті клініко-генеалогічного обстеження складено і проаналізовано 215 родоводів сімей респондентів, зібрано дані про кількість родичів, їхній ступень спорідненості 3 пробандом, наявність захворювань, професійну діяльність тощо. Під час аналізу родоводів дослідну і контрольну групи поділили на дві підгрупи. До першої підгрупи увійшли респонденти, родичі яких мали в анамнезі ознаки БЛП, до другої підгрупи - особи, у родинах яких не було виявлено осіб 3 ознаками БЛП (табл. 5).

Для 3'ясування ролі генетичної компоненти у розвиткові БЛП було визначено частоту сімейних випадків

Таблиця 5 дослідження та оцінка ризику впливу родоводів

\begin{tabular}{|c|c|c|c|c|c|c|c|c|c|}
\hline \multirow{2}{*}{\multicolumn{2}{|c|}{ Група обстежених }} & \multicolumn{2}{|c|}{$\begin{array}{c}\text { Респонденти, } \\
\text { анамнез БЛП } \\
\text { «+» }\end{array}$} & \multicolumn{2}{|c|}{$\begin{array}{c}\text { Респонденти, } \\
\text { анамнез БЛП } \\
\text { «-» }\end{array}$} & \multirow[t]{2}{*}{$P, \chi^{2}$} & \multirow[t]{2}{*}{$\mathrm{RR}(\mathrm{Cl})$} & \multirow[t]{2}{*}{$\begin{array}{c}E F(2), \\
\%\end{array}$} & \multirow[t]{2}{*}{$\begin{array}{l}\text { Оцінка } \\
\text { ризику }\end{array}$} \\
\hline & & $\mathrm{n}$ & $\mathrm{M} \pm \mathrm{m}, \%$ & $\mathrm{n}$ & $M \pm m, \%$ & & & & \\
\hline Дослідна, n & 90 & 46 & $51,1 \pm 5,3$ & 44 & $48,9 \pm 5,3$ & \multirow{2}{*}{$\begin{array}{r}P \leq 0,001 \\
\chi^{2}=16,75\end{array}$} & \multirow{2}{*}{$\begin{array}{c}1,912 \\
(1,821-1,933)\end{array}$} & \multirow{2}{*}{$47-48$} & \multirow{2}{*}{$\begin{array}{l}\text { Середній } \\
\text { ризик }\end{array}$} \\
\hline Контрольна, n & 125 & 30 & $24,0 \pm 3,8$ & 95 & $76,0 \pm 3,8$ & & & & \\
\hline
\end{tabular}

Таблиця 6

Частотний розподіл виникнення бронхолегеневої патології у родинах респондентів дослідження з професійною спадкоємністю

\begin{tabular}{|c|c|c|c|c|c|c|}
\hline \multirow{3}{*}{\multicolumn{2}{|c|}{$\begin{array}{c}\text { Група } \\
\text { обстежених }\end{array}$}} & \multicolumn{4}{|c|}{ Респонденти дослідження з професійною спадкоємністю } & \multirow{3}{*}{$P, \chi^{2}$} \\
\hline & & \multicolumn{2}{|c|}{ Анамнез БЛП «+» } & \multicolumn{2}{|c|}{ Анамнез БЛП «-» } & \\
\hline & & $\mathrm{n}$ & $M \pm m, \%$ & $\mathrm{n}$ & $M \pm m, \%$ & \\
\hline Дослідна, n & 15 & 15 & 100,0 & 0 & 0 & \multirow{2}{*}{$\begin{array}{l}P \leq 0,01, \\
\chi^{2}=5,65\end{array}$} \\
\hline Контрольна, n & 12 & 8 & $66,7 \pm 13,6$ & 4 & $33,3 \pm 13,6$ & \\
\hline
\end{tabular}


виникнення БЛП серед респондентів дослідження. Встановлено достовірно вищу різницю кількості сімейних випадків БЛП у дослідній групі $(51,1 \%)$ порівняно з частотою сімейних випадків захворювань дихальної системи у контрольній групі (24,0\%, $\left.\chi^{2}=16,75 ; \quad \mathrm{P}<0,001\right)$. Обчислення коефіцієнта FA проводили за формулою 1: $F A=51,1 / 24,0=2,1$. Отже, вірогідність ризику розвитку БЛП в осіб з обтяжливим сімейним анамнезом на БЛП у 2,1 рази вища, ніж у шахтарів і працівників АЦЗ, родичі яких не мали в анамнезі патології дихальної системи. Оцінка етіологічної частки ризику впливу обтяжливої спадковості у сім'ях респондентів дослідження EF(2) свідчить про значну (47-48\%) частку внеску цього чинника у розвиток БЛП.

Таким чином, сума EF (сумарне) етіологічних часток виробничих факторів $E F(1)$ (41-43\%) та обтяжливої спадковості EF(2) (47-48\%) відповідно до формули 6 становить $88-93 \%$.

У подальшому було проаналізовано сім'ї з професійною спадкоємністю праці у шкідливих і небезпечних умовах азбестопереробної і вугільної промисловості та з обтяжливим родинним анамнезом на БлП. Так, у дослідній групі виявлено 34 (37,8\%) сім'ї 3 професійною спадкоємністю, 3 них 26 (56,5\%) сімей 3 підгрупи з обтяжливим родинним анамнезом на БЛП і 8 (18,2\%) сімей з підгрупи без обтяжливого анамнезу на БЛП. 326 сімей у 15 (57,7\%) простежувалася професійна спадкоємність у професіях вугільної та азбестопереробної промисловості та захворюваність у родичів пробанда на БЛП. Так, у контрольній групі виявлено 56 (44,8\%) сімей, які мали професійну спадкоємність, $з$ них 16 (53,3\%) було із першої підгрупи. 316 виявлених родин у половини $(50,0 \%)$ одночасно простежувалися професійна спадкоємність та обтяжливий анамнез на захворювання дихальної системи. При визначенні частот сімейних випадків виникнення БЛП у предків з професійною спадкоємністю в азбестопереробній та вугільній промисловості встановлено достовірно вищу різницю кількості сімейних випадків БЛП серед предків дослідної групи, першої підгрупи (з обтяжливим сімейним анамнезом на БЛП), яка становила 100\% порівняно з відповідною частотою серед предків респондентів контрольної групи - 66,7\% ( 2=5,65; p<0,01) (табл. 6).

Коефіцієнт FA у респондентів дослідної і контрольної груп, предки яких створили сімейні професійні династії і мали в анамнезі БЛП, становив $F A=100,0 / 66,7=1,5$. Таким чином, вірогідність ризику розвитку БЛП у шахтарів і працівників АЦЗ з родинною професійною спадкоємністю та обтяжливим на БЛП сімейним анамнезом в 1,5 рази вища, ніж у працівників, родичі яких не хворіли на БЛП та не працювали у шкідливих і небезпечних умовах праці.

\section{Висновки}

1. Комплексна гігієнічна оцінка умов праці за розрахунковими показниками свідчить про те, що на основних робочих місцях гірників вугільних шахт рівень впливу шкідливих виробничих чинників (КУП 3.3-4) визначається максимальною сумою балів 18-20. На робочих місцях працівників основних професій азбестоцементних заводів рівень впливу шкідливих виробничих чинників за тією ж шкалою становив 7-9 балів (КУП 3.2-3.4) порівняно 3 шахтарями, що свідчить про її більшу безпечність.

2. Вплив на організм працівників понаднормативних концентрацій пилу переважно фіброгенної дії (КУП 3.3-3.4), несприятливих параметрів мікроклімату та емоційних навантажень (КУП 3.1-3.2) € характерним для обох досліджених груп. Вплив небезпечних та шкідливих рівнів вібрації (КУП 3.4-4), шуму (КУП 3.33.4), а також важкої фізичної праці (за інтегральною оцінкою - КУП 3.3), більш характерний для основних професійних груп гірників.

3. Аналіз результатів гігієнічної оцінки умов праці та клініко-генеалогічного обстеження осіб, експонованих шкідливими виробничими факторами, свідчить, що обтяжлива спадковість на бронхолегеневу патологію може бути додатковою причиною (Фактором ризику) виникнення хвороб дихальної системи професійної етіології.

4. Встановлено причиннонаслідковий зв'язок бронхолегеневої патології з умовами праці робітників основних професій вугільної та азбестопереробної промисловості. Межі відносного ризику розвитку цієї патології $(R R=1,69-1,76)$ відповідають середньому ризику розвитку бронхолегеневої патології 3 етіологічною часткою шкідливих умов праці EF(1) $41-43 \%$.

5. Встановлено, що у родинах 3 обтяжливим сімейним анамнезом на бронхолегеневу патологію ризик її розвитку вдвічі вищий порівняно з родинами без позитивних сімейних випадків захворювань дихальної системи ( $\mathrm{FA}=2,1$; $\mathrm{P} \leq 0,001$; $\left.\chi^{2}=16,75\right)$. Оцінка етіологічної частки ризику впливу обтяжливої спадковості EF(2) свідчить, що її внесок у розвиток захворювань дихальної системи становить 47-48\%.

6. Сумарний вплив EF (сумарне) на розвиток бронхолегеневої патології: виробничих факторів EF (1) (41-43\%) та обтяжливої спадковості EF(2) (47-48\%) становив у даному дослідженні 88-93\%. Застосування даної методики для визначення часток етіологічних факторів у становленні бронхолегеневої патології професійного генезу потребує подальшого вивчення.

7. У родинах з обтяжливим сімейним анамнезом на бронхолегеневу патологію і професійною спадкоємністю роботи в азбестопереробній і вугіль- 
7. Кундиев Ю.И., Чернюк В.И., Витте П.Н. Изучение профессионального риска на Украине. Медицина труда и промышленная экология. 1999. № 4. С. 6-9.

8. Бучинська Л.Г., Поліщук Л.З., Глущенко Н.М. Клініко-генеалогічне дослідження як перший етап обстеження хворих на рак ендометрія. Онкологія. 2006. Т. 8 (3). C. 245-249.

9. Измеров Н.Ф., Денисов Э.И. Профессиональный риск для здоровья работников. Москва : Тровант, 2003. $448 \mathrm{c}$.

10. Несіна І.П., Юрченко Н.П., Глущенко Н.М., Проскурня Л.А., Бучинська Л.Г. Молекулярнобіологічні особливості серозного раку яєчника хворих 3 агрегацією пухлинної патології у родоводах. Онкологія. 2017. Т. 19 (2). 110-117.

11. Kuschel B., Auranen A., McBride S., Novik K.L., Antoniou A. Variants in doublestrand break repair genes and breast cancer susceptibility. Hum Mol Genet. 2002. № 11. P. 1399-1440.

12. Suter C.M., Martin D.L., Ward R.L. Germline epimutation of MLH1 in individuals with multiple cancers. Nat Genet. 2004. Vol. 36. P. 497-501.

13. Вітте П.М. Методи досліджень в епідеміології неінфекційних захворювань (Довідково-методичний посібник). Київ, 2005. 118 с.

REFERENCES

1. Andrushchenko T.A. and Basanets A.V. Ukrainskyi zhurnal z problem medytsyny pratsi. 2015 ; 3 (44) : 75-82

(in Ukrainian).

2. Kuzmina L.P. Mediko-ekologicheskie problemy zdorovia rabotayushchikh. $2004 ; 2$ : 25 30 (in Russian).

3. Mukhin V.V. Meditsina truda v ugolnoy promyshlennosti : monografiya [Occupational Medicine in Coal Industry: Monograph]. Donetsk ; 2002 : 204 p. (in Russian).

4. Nahorna A.M., Sokolova M.P., Vitte P.M., Kononova I.G. and Piatnytsia-Horpynchenko N.K. Ukrainskyi zhurnal z problem medytsyny pratsi. 2016 ; 1 (46) : 3-17 (in Ukrainian).

5. International Labour Office (ILO) Natsionalnyi profil z bezpeky ta hihiieny pratsi. Ukraina 2018. Proekt ES-MOP «Zmitsnennia administratsii pratsi z metoyu pokrashchennia umov pratsi I podolannia nezadeklarovanoi pratsi» [National Profile on Occupational Safety and Health. Ukraine 2018. EU-ILO Project «Strengthening of Labour Administration for the Improvement of the Conditions of Work and Overcoming of Undeclared Work». URL www. ilo.org/UkraineEUProject (in Ukrainian).

6. Perederii G.S., Lastkov D.O. and Partas O.V. Udoskonalennia sanitarno-hihiienichnoho monitorynhu vplyvu umov pratsi na zdorovia hirnykiv vuhilnykh shakht : monohrafiia [Improvement of Sanitary-andHygienic Monitoring of the Influence of the Conditions of Work on the Health of Miners in Coal Mines: Monograph]. Donetsk : Svit knyhy ; 2012 : 319 p. (in Ukrainian).

7. Kundiiev Yu.I., Cherniuk V.I. and Vitte P.N. Meditsina truda $i$ promyshlennaia ekologiia. 1999 ; 4 ; 6-9 (in Russian).

8. Buchynska L.G., Polishchuk L.Z. and Hlushchenko N.M. Oncology. 2006 ; 8 (3) : 245-249 (in Ukrainian).

9. Izmerov N.F. and Denisov E.I. Profrssionalnyi risk dlia zdorovia rabotnikov [Occupational Health Risk for Workers]. Moscow : Trovant ; 2003 : 448 c. (in Russian).

10. Nesina I.P., Yurchenko N.P., Hlushchenko N.M., Proskurnia L.A. and Buchynska L.G. Oncology. 2017 ; 19 (2) : 110-117 (in Ukrainian).

11. Kuschel B., Auranen A., McBride S., Novik K.L. and Antoniou A. Hum Mol Genet. 2002 ; 11 : 1399-1440.

12. Suter C.M., Martin D.L. and Ward R.L. Nat Genet. 2004 ; 36 : 497-501.

13. Vitte P.M. Metody doslidzhen u epidemiolohii neinfektsiinykh zakhvoriuvan (Dovidkovo-metodychnyi posibnyk) [Methods of Research in the Epidemiology of NonInfectious Diseases (Referenceand-Methodical Manual)]. Kyiv ; 2005 : $118 \mathrm{p}$.

(in Ukrainian).

Надійшла до редакції 24. 10.2018 графія. Донецьк : Світ книги 2012. 319 c. 